\title{
Predicting Maintenance Doses of Vancomycin for Hospitalized Patients Undergoing Hemodialysis
}

\author{
Wasim S El Nekidy, Maher M El-Masri, Greg S Umstead, and Michelle Dehoorne-Smith
}

\begin{abstract}
Background: Methicillin-resistant Staphylococcus aureus is a leading cause of death in patients undergoing hemodialysis. However, controversy exists about the optimal dose of vancomycin that will yield the recommended pre-hemodialysis serum concentration of $15-20 \mathrm{mg} / \mathrm{L}$.

Objective: To develop a data-driven model to optimize the accuracy of maintenance dosing of vancomycin for patients undergoing hemodialysis.

Methods: A prospective observational cohort study was performed with 164 observations obtained from a convenience sample of 63 patients undergoing hemodialysis. All vancomycin doses were given on the floor after completion of a hemodialysis session. Multivariate linear generalized estimating equation analysis was used to examine independent predictors of pre-hemodialysis serum vancomycin concentration.

Results: Pre-hemodialysis serum vancomycin concentration was independently associated with maintenance dose $(B=0.658, p<0.001)$, baseline pre-hemodialysis serum concentration of the drug $(B=0.492$, $p<0.001)$, and interdialytic interval $(B=-2.133, p<0.001)$. According to the best of 4 models that were developed, the maintenance dose of vancomycin required to achieve a pre-hemodialysis serum concentration of $15-20 \mathrm{mg} / \mathrm{L}$, if the baseline serum concentration of the drug was also $15-20 \mathrm{mg} / \mathrm{L}$, was $5.9 \mathrm{mg} / \mathrm{kg}$ with interdialytic interval of $48 \mathrm{~h}$ and $7.1 \mathrm{mg} / \mathrm{kg}$ with interdialytic interval of $72 \mathrm{~h}$. However, if the baseline pre-hemodialysis serum concentration was $10-14.99 \mathrm{mg} / \mathrm{L}$, the required dose increased to $9.2 \mathrm{mg} / \mathrm{kg}$ with an interdialytic interval of $48 \mathrm{~h}$ and $10.0 \mathrm{mg} / \mathrm{kg}$ with an interdialytic interval of $72 \mathrm{~h}$.

Conclusions: The maintenance dose of vancomycin varied according to baseline pre-hemodialysis serum concentration of the drug and interdialytic interval. The current practice of targeting a pre-hemodialysis concentration of $15-20 \mathrm{mg} / \mathrm{L}$ may be difficult to achieve for the majority of patients undergoing hemodialysis.
\end{abstract}

Keywords: vancomycin, dosing, hemodialysis

Can J Hosp Pharm. 2016;69(5):341-7

\section{RÉSUMÉ}

Contexte : Les infections à Staphylococcus aureus résistant à la méthicilline comptent parmi les principales causes de mortalité chez les patients traités par hémodialyse. Or, les avis sont partagés quant à la dose optimale de vancomycine qui permet d'atteindre la concentration sérique recommandée de $15-20 \mathrm{mg} / \mathrm{L}$ préalablement à l'hémodialyse.

Objectif : Mettre au point un modèle guidé par des données afin d'optimiser l'exactitude de la dose d'entretien de vancomycine chez les patients qui subissent une hémodialyse.

Méthodes : Une étude de cohorte prospective observationnelle a été menée à partir de 164 observations obtenues d'un échantillon de commodité de 63 patients traités par hémodialyse. Toutes les doses de vancomycine ont été données à l'unité de soins courants après la fin d'une séance d'hémodialyse. Une analyse de régression linéaire multiple par équation d'estimation généralisée a été effectuée pour cerner les variables indépendantes qui permettent de prévoir la concentration sérique de vancomycine préalablement à l'hémodialyse.

Résultats : La concentration sérique de vancomycine avant hémodialyse a été associée de façon indépendante à l'intervalle entre deux dialyses $(B=-2,133, p<0,001)$, à la dose d'entretien $(B=0,658, p<0,001)$ et à la concentration sérique initiale du médicament préalablement à l'hémodialyse $(B=0,492, p<0,001)$. Selon les quatre meilleurs modèles élaborés, la dose d'entretien de vancomycine nécessaire pour atteindre une concentration sérique de $15-20 \mathrm{mg} / \mathrm{L}$ avant hémodialyse, si la valeur initiale était aussi de $15-20 \mathrm{mg} / \mathrm{L}$, était de $5,9 \mathrm{mg} / \mathrm{kg}$ pour un intervalle de $48 \mathrm{~h}$ entre deux dialyses et de $7,1 \mathrm{mg} / \mathrm{kg}$ pour un intervalle de $72 \mathrm{~h}$ entre deux dialyses. Or, si la concentration sérique initiale préalablement à l'hémodialyse se situait entre 10 et $14,99 \mathrm{mg} / \mathrm{L}$, la dose nécessaire augmentait à 9,2 mg/ $\mathrm{kg}$ pour un intervalle de $48 \mathrm{~h}$ entre deux dialyses et à $10,0 \mathrm{mg} / \mathrm{kg}$ pour un intervalle de $72 \mathrm{~h}$ écoulé entre deux dialyses.

Conclusions : La dose d'entretien de vancomycine variait en fonction de la concentration sérique initiale du médicament préalablement à l'hémodialyse et en fonction de l'intervalle entre deux dialyses. La pratique actuelle voulant qu'on vise une concentration préalable à l'hémodialyse de $15-20 \mathrm{mg} / \mathrm{L}$ peut être difficile à respecter chez la majorité des patients subissant une hémodialyse.

Mots clés : vancomycine, posologie, hémodialyse 


\section{INTRODUCTION}

Tnfections are among the leading causes of death among patients

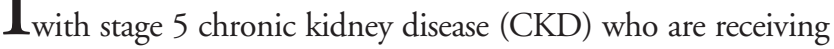
hemodialysis. ${ }^{1-3}$ Such infections are often caused by gram-positive bacteria, especially methicillin-resistant Staphylococcus aureus (MRSA). ${ }^{3-5}$ It has been reported that $S$. aureus infections account for $39 \%$ of all cases of catheter-related bacteremia among patients undergoing hemodialysis and that MRSA accounts for about $60 \%$ of all $S$. aureus infections. ${ }^{6,7}$

For more than 5 decades, vancomycin has been the treatment of choice for MRSA in patients undergoing hemodialysis. ${ }^{4,8,9}$ However, dosing of this drug in this patient population is still not well established. One study correlated a pre-hemodialysis vancomycin concentration of $5-10 \mathrm{mg} / \mathrm{L}$ with clinical and microbiological failure in patients with permanent catheterrelated soft-tissue infections. ${ }^{4}$ Current vancomycin guidelines recommend that the trough serum concentration should be maintained between 15 and $20 \mathrm{mg} / \mathrm{L}$ for serious infections, ${ }^{9-11}$ but they do not address dosing strategies or appropriate pre-hemodialysis concentration for administration of vancomycin to patients undergoing hemodialysis. ${ }^{3,12}$ Furthermore, the recommended serum concentration of $15-20 \mathrm{mg} / \mathrm{L}$ was validated with patients who had normal kidney function, but the accuracy of this range for patients with stage $5 \mathrm{CKD}$ who were receiving hemodialysis was not clearly addressed.

Several factors have been shown to affect the removal of vancomycin during hemodialysis sessions: the use of high-flux dialysis membranes, blood flow rate, dialysate flow rate, timing of vancomycin administration, duration of the session, presence of residual renal function, and actual body weight., ${ }^{2,3,6,12}$ For instance, in various studies, different high-flux dialysis membranes removed different amounts of the drug (25\% to $50 \%$ ) in each dialysis session. ${ }^{13-16}$ This variability may have been related to the differing composition of the dialysis membranes and whether or not vancomycin was infused during the last 30-90 min of dialysis. ${ }^{17}$ Use of these high-flux filters was implemented at St John Hospital and Medical Center, in Detroit, Michigan, in 2009. The institution's protocol targets a prehemodialysis serum vancomycin concentration of $15-20 \mathrm{mg} / \mathrm{L}$ for all patients requiring vancomycin therapy.

The primary purpose of this study was to develop a prediction equation to assist clinicians in deciding on the optimal maintenance dose of vancomycin needed for hemodialysis patients to achieve the target pre-hemodialysis serum concentration of the drug. The secondary purposes of the study were to develop a data-driven vancomycin dosing nomogram and to explore the clinical feasibility of achieving a pre-hemodialysis serum vancomycin concentration of $15-20 \mathrm{mg} / \mathrm{L}$ in these patients.

\section{METHODS}

\section{Study Design}

Upon approval of the study protocol by the St John Hospital and Medical Centre Institutional Review Board, a prospective observational cohort study was conducted at this 772-bed teaching hospital in east Detroit, Michigan, with a convenience sample of 63 established hemodialysis patients, between January and June 2010. This sample exceeded the minimum sample of 55 patients needed to detect a modest effect size of 0.15 , assuming $\alpha$ of 0.05 and $80 \%$ power for a linear regression model of 5 independent predictors (the model developed during the course of the study had 3 independent predictors). Patients were included in the study if they were 18 years of age or older, had stage $5 \mathrm{CKD}$ with established hemodialysis (3 sessions per week), had suspected or confirmed MRSA infection, received at least 2 doses of vancomycin during the hospital admission (one loading dose and at least the first maintenance dose), and had serum vancomycin concentration measured after the first maintenance dose and before subsequent hemodialysis sessions. For the hemodialysis, high-flux filters (Optiflux F-160, Fresenius), with a surface area of $1.6 \mathrm{~m}^{2}$, were used.

Eligible patients with suspected or confirmed MRSA infection who received maintenance doses of vancomycin were enrolled in the study. All of the doses were given on hospital floors within a maximum of $6 \mathrm{~h}$ after completion of hemodialysis (i.e., doses were not given during the last 30-90 min of hemodialysis). The institutional protocol recommends the administration of vancomycin $500 \mathrm{mg} \mathrm{IV}$ after each hemodialysis session; however, pharmacists were left to use their clinical judgment for selection of the maintenance dose, as per the institution's medial directive.

\section{Definition of Variables and Data Sources}

Patient body weight was obtained from electronic medical records. Interdialytic interval was the approximate time between 2 consecutive hemodialysis sessions. Baseline pre-hemodialysis serum vancomycin concentration was the concentration of drug that resulted from the loading dose or maintenance dose measured within a maximum of $6 \mathrm{~h}$ before commencement of the first hemodialysis session during the particular admission (either during morning laboratory testing or just before the hemodialysis session). Established hemodialysis patients were those with stage $5 \mathrm{CKD}$ who were receiving hemodialysis. The vancomycin dose was measured in milligrams per kilogram, and no individual dose exceeded $2000 \mathrm{mg}$. Patients with suspected MRSA infection were those with an infection such as cellulitis, abscess, or osteomyelitis that was treated with vancomycin in the absence of any confirmatory culture results. 


\section{Data Analysis}

Data were analyzed using SPSS statistical software, version 22.0 (IBM, Armonk, New York). Before analysis, the data were explored for accuracy and possible violations of statistical assumptions, including multicollinearity, multivariate outliers, and multivariate normality. Descriptive statistics, such as general frequencies, means, and standard deviations, were calculated to describe the demographic and prognostic characteristics of the study sample. Given the clustered nature of the data (i.e., individual patients having multiple observations), multivariate linear generalized estimating equation (GEE) analysis was conducted to examine independent predictors of the actual pre-hemodialysis serum vancomycin concentration. Although it might be intuitive to use vancomycin dose as the outcome variable in the GEE analysis, pre-hemodialysis serum concentration was used instead, because this measure is a function of the dose that the patient receives.

Specifically, the analysis was performed on 164 observations obtained from the 63 patients. Insignificant variables were removed from the final GEE model before the analysis was repeated to yield a parsimonious model that was explained only by the significant variables. To evaluate the optimal cut-off point for pre-hemodialysis serum vancomycin concentration, the predicted values (generated by the GEE analysis) and the actual measured baseline values were categorized according to various cut-off points. This allowed cross-tabulation and calculation of the classification indices (i.e., sensitivity, specificity, and negative and positive predictive values) of the resulting models, which in turn allowed assessment of the most clinically relevant cut-off point based on the study data. Statistical significance was established using a 2-tailed $\alpha$ of 0.05 .

\section{RESULTS}

Sample and dialysis characteristics are presented in Table 1. The results of the GEE analysis (Table 2) suggest that prehemodialysis serum vancomycin concentration was independently associated with maintenance dose $(B=0.658, p<0.001)$, baseline pre-hemodialysis serum concentration $(B=0.492$, $p<0.001)$, and interdialytic interval $(B=-2.133, p<0.001)$. These results were associated with a regression constant of 6.329 , which yielded the following prediction equation (where $\mathrm{HD}=$ hemodialysis):

$$
\begin{aligned}
\text { Pre-HD serum vancomycin }= & 6.329+(0.658) *(\text { vancomycin dose }[\mathrm{mg} / \mathrm{kg}]) \\
& +(0.492) *(\text { baseline serum vancomycin }[\mathrm{mg} / \mathrm{L}]) \\
& +(-2.133) *(\text { interdialytic interval) })
\end{aligned}
$$

where interdialytic interval of $48 \mathrm{~h}$ had a value of 0 and interdialytic interval of $72 \mathrm{~h}$ had a value of 1 .

Table 3 displays the targeted vancomycin dose based on knowledge of the baseline pre-hemodialysis serum vancomycin concentration, the target pre-hemodialysis serum vancomycin

Table 1. Patient and Dialysis Characteristics

\begin{tabular}{lc} 
Characteristic & $\begin{array}{c}\text { No. (\%) of Participants* } \\
(\boldsymbol{n}=\mathbf{6 3})\end{array}$ \\
\hline Age (years) (mean \pm SD) & $60.9 \pm 15.2$ \\
\hline Sex, male & $33(52)$ \\
\hline Ethnic background & $16(25)$ \\
White & $47(75)$ \\
African American & $57(90)$ \\
\hline Comorbid conditions & $38(60)$ \\
Hypertension & $51(81)$ \\
Diabetes mellitus & $19(30)$ \\
Heart disease & $83.4 \pm 25.2(37-180)$ \\
Respiratory disease & $28.6 \pm 9.5$ \\
\hline Body weight (kg) (mean \pm SD, range) & \\
Body mass index (kg/m²) (mean \pm SD) & $358.7 \pm 43.8$ \\
\hline Hemodialysis variables (mean \pm SD, range) & $3.4 \pm 0.37$ \\
Blood flow rate (mL/min) & $52.6 \pm 13.7(24-96)$ \\
Duration of hemodialysis (h) & $792 \pm 37.3$ \\
Interdialytic interval (h) & \\
Dialysate flow rate (mL/min) & $9.14 \pm 4 \quad(3.03-22.06)$ \\
Vancomycin variables (mean \pm SD, range) & $747 \pm 317(500-2000)$ \\
Dose by weight (mg/kg) & $21.56 \pm 4.94(8.2-36.1)$ \\
Total dose (mg) & $34(54)$ \\
Pre-hemodialysis concentration (mg/L) & $20(32)$ \\
Infection type & $6(10)$ \\
Bacteremia related to graft/catheter & $3(5)$ \\
Skin and soft tissue &
\end{tabular}


This single copy is for your personal, non-commercial use only.

For permission to reprint multiple copies or to order presentation-ready copies for distribution, contact CJHP at cjhpedit@cshp.ca

Table 2. Generalized Estimating Equation Model Identifying Predictors of Serum Vancomycin Concentration before Hemodialysis*

\begin{tabular}{lrrrr} 
Variable & $\boldsymbol{B}$ & SE & Wald Z & $\boldsymbol{p}$ Valuet \\
\hline Interdialytic interval 72 $\mathrm{h}$ (reference: $48 \mathrm{~h})$ & -2.133 & 0.5806 & 13.499 & $<0.001$ \\
Maintenance dose $(\mathrm{mg} / \mathrm{kg})$ & 0.658 & 0.0822 & 64.170 & $<0.001$ \\
Baseline pre-hemodialysis concentration $(\mathrm{mg} / \mathrm{L})$ & 0.492 & 0.0737 & 44.649 & $<0.001$ \\
\hline B &
\end{tabular}

$B=$ unstandardized regression coefficient, $\mathrm{SE}=$ standard error, Wald $\mathrm{Z}=$ test statistic for the linear generalized estimating equation analysis.

*Pre-hemodialysis serum vancomycin concentration $=6.329+(0.658)$ * $($ vancomycin dose $[\mathrm{mg} / \mathrm{kg}])+(0.492)$ *

(baseline serum vancomycin concentration [mg/L]) $+(-2.133)$ * (interdialytic interval [where $48 \mathrm{~h}=0 ; 72 \mathrm{~h}=1]$ ).

tBased on a 2-tailed $\alpha$ of 0.05 .

concentration, and the interdialytic interval. According to this model, if the targeted serum concentration is $15-20 \mathrm{mg} / \mathrm{L}$ and the baseline pre-hemodialysis serum vancomycin concentration is also $15-20 \mathrm{mg} / \mathrm{L}$, the mean required dose (and standard deviation) is $5.9 \pm 0.82 \mathrm{mg} / \mathrm{kg}$ for an interdialytic interval of $48 \mathrm{~h}$ and $7.1 \pm 1.99 \mathrm{mg} / \mathrm{kg}$ for an interdialytic interval of $72 \mathrm{~h}$. However, if the baseline serum concentration is between 10 and $14.99 \mathrm{mg} / \mathrm{kg}$, the required dose increases to $9.2 \mathrm{mg} / \mathrm{kg}$ for an interdialytic interval of $48 \mathrm{~h}$ and $10.0 \mathrm{mg} / \mathrm{kg}$ for an interdialytic interval of $72 \mathrm{~h}$.

Table 4 shows 4 classification models based on different cut-off points for the actual and predicted pre-hemodialysis serum vancomycin concentrations, reflecting the sensitivity and specificity of each model with regard to the dose associated with those concentrations. Model 4 had the best characteristics overall: sensitivity of $96 \%$, positive predictive value of $75 \%$, and negative predictive value of $75 \%$. It can also be inferred from Model 4 that the vancomycin dose for the $65.9 \%$ of patients $(108 / 164)$ whose predicted serum concentrations matched their actual serum concentrations within the range of $15-25 \mathrm{mg} / \mathrm{L}$ was
$8.88 \mathrm{mg} / \mathrm{kg}$. However, according to Model 2, only $12.8 \%$ of patients (21/164) were correctly classified when the target prehemodialysis serum vancomycin concentration was narrowed to $15-20 \mathrm{mg} / \mathrm{L}$.

\section{DISCUSSION}

Optimal vancomycin dosing in patients who are undergoing hemodialysis has been controversial. Clinicians commonly select the dose of vancomycin on the basis of actual body weight $(\mathrm{mg} / \mathrm{kg})$ in accordance with data generated from patients with normal kidney function. ${ }^{2,9}$ Furthermore, the goal for trough serum vancomycin concentration of $15-20 \mathrm{mg} / \mathrm{L}$ that is recommended by current guidelines ${ }^{9-11}$ was validated with data from patients with normal kidney function. This situation creates uncertainty about the applicability of current practices pertaining to maintenance dosing of vancomycin and the associated prehemodialysis serum vancomycin concentrations in patients with stage $5 \mathrm{CKD}$. The current study used data from patients with stage $5 \mathrm{CKD}$ who were receiving hemodialysis to provide

Table 3. Classification of Vancomycin Dose and Pre-HD Serum Concentration for Different Interdialytic Intervals

\begin{tabular}{|c|c|c|c|c|c|}
\hline \multirow{3}{*}{$\begin{array}{l}\text { Baseline Pre-HD Serum } \\
\text { Conc'n of Vancomycin } \\
\text { (mg/L) }\end{array}$} & \multirow{3}{*}{$\begin{array}{l}\text { Target Pre-HD Serum } \\
\text { Conc'n of Vancomycin } \\
\text { for Next Dialysis (mg/L) }\end{array}$} & \multicolumn{4}{|c|}{$\begin{array}{c}\text { Interdialytic Interval; } \\
\text { Vancomycin Dose (mg/kg) }\end{array}$} \\
\hline & & \multicolumn{2}{|l|}{$48 \mathrm{~h}$} & \multicolumn{2}{|l|}{$72 \mathrm{~h}$} \\
\hline & & Mean \pm SD & $n$ & Mean \pm SD & $n$ \\
\hline$<10$ & $\begin{array}{c}15-20 \\
20.01-25\end{array}$ & $\begin{array}{c}\text { NA } \\
17.9 \pm 3.08\end{array}$ & $\begin{array}{l}0 \\
4\end{array}$ & $\begin{array}{c}15.2 \pm 2.68 \\
\text { NA }\end{array}$ & $\begin{array}{l}3 \\
0\end{array}$ \\
\hline 10-14.99 & $\begin{array}{c}10-14.99 \\
15-20 \\
20.01-25\end{array}$ & $\begin{array}{c}\text { NA } \\
9.2 \pm 1.46 \\
14.7 \pm 1.94\end{array}$ & $\begin{array}{r}0 \\
5 \\
11\end{array}$ & $\begin{array}{c}5.3 \pm 0 \\
10.0 \pm 2.91 \\
16.5 \pm 3.20\end{array}$ & $\begin{array}{l}1 \\
2 \\
3\end{array}$ \\
\hline 15-20 & $\begin{array}{c}<15 \\
15-20 \\
20.01-25\end{array}$ & $\begin{array}{c}\text { NA } \\
5.9 \pm 0.82 \\
11.0 \pm 2.19\end{array}$ & $\begin{array}{r}0 \\
11 \\
25\end{array}$ & $\begin{array}{c}\text { NA } \\
7.1 \pm 1.99 \\
14.5 \pm 2.82\end{array}$ & $\begin{array}{r}0 \\
13 \\
6\end{array}$ \\
\hline $20.1-25$ & $\begin{array}{c}<15 \\
15-20 \\
20.01-25\end{array}$ & $\begin{array}{c}\text { NA } \\
4.0 \pm 0.81 \\
6.2 \pm 1.64\end{array}$ & $\begin{array}{r}0 \\
3 \\
25\end{array}$ & $\begin{array}{c}\text { NA } \\
4.9 \pm 0.65 \\
10.0 \pm 2.95\end{array}$ & $\begin{array}{r}0 \\
6 \\
10\end{array}$ \\
\hline$\overline{15-25^{*}}$ & $\begin{array}{l}<15 \\
15-25\end{array}$ & $\begin{array}{c}\text { NA } \\
20.7 \pm 2.60\end{array}$ & $\begin{array}{r}0 \\
39\end{array}$ & $\begin{array}{c}\text { NA } \\
19.9 \pm 2.80\end{array}$ & $\begin{array}{r}0 \\
25\end{array}$ \\
\hline $25.01-35$ & $\begin{array}{c}\leq 20 \\
20.01-25\end{array}$ & $\begin{array}{c}\text { NA } \\
6.5 \pm 1.01\end{array}$ & $\begin{array}{r}0 \\
12\end{array}$ & $\begin{array}{c}\text { NA } \\
6.3 \pm 1.60\end{array}$ & $\begin{array}{l}0 \\
6\end{array}$ \\
\hline
\end{tabular}

Conc'n = concentration, HD = hemodialysis, NA = not applicable, SD = standard deviation.

* This range was created by merging the ranges of $15-20$ and $20.1-25$ into a single category to allow all clinically plausible scenarios to be presented. 
This single copy is for your personal, non-commercial use only.

For permission to reprint multiple copies or to order presentation-ready copies for distribution, contact CJHP at cjhpedit@cshp.ca

Table 4. Classification Indices Highlighting Sensitivity, Specificity, PPV, and NPV According to Different Ranges of Predicted and Measured Serum Concentration of Vancomycin

\begin{tabular}{|c|c|c|c|c|c|c|c|c|c|}
\hline \multirow{3}{*}{$\begin{array}{l}\text { Pre-HD Concentration } \\
\text { Cut-off Range (mg/L) }\end{array}$} & \multirow{3}{*}{$\begin{array}{l}\text { Predicted Value of } \\
\text { Serum Vancomycin* }\end{array}$} & \multicolumn{4}{|c|}{$\begin{array}{l}\text { Measured Value of } \\
\text { Serum Vancomycin* }\end{array}$} & \multirow{3}{*}{ Sensitivity } & \multirow{3}{*}{ Specificity } & \multirow{3}{*}{ PPV } & \multirow{3}{*}{ NPV } \\
\hline & & \multicolumn{2}{|r|}{ Yes } & \multicolumn{2}{|c|}{ No } & & & & \\
\hline & & $n$ & Dose (mg/kg) & $n$ & Dose (mg/kg) & & & & \\
\hline \multirow[t]{2}{*}{ Model 1: 10-25 } & & & & & & 0.97 & 0.35 & 0.82 & 0.77 \\
\hline & $\begin{array}{l}\text { Yes } \\
\text { No }\end{array}$ & $\begin{array}{r}119 \\
5\end{array}$ & $\begin{array}{r}8.82 \\
11.36\end{array}$ & $\begin{array}{l}27 \\
13\end{array}$ & $\begin{array}{r}10.38 \\
8.66\end{array}$ & & & & \\
\hline \multirow[t]{3}{*}{ Model 2: 15-20 } & & & & & & 0.52 & 0.81 & 0.53 & 0.80 \\
\hline & Yes & 21 & 7.47 & 22 & 6.96 & & & & \\
\hline & No & 27 & 9.01 & 94 & 10.06 & & & & \\
\hline \multirow[t]{2}{*}{ Model 3: 10-20 } & & & & & & 0.53 & 0.83 & 0.63 & 0.76 \\
\hline & $\begin{array}{l}\text { Yes } \\
\text { No }\end{array}$ & $\begin{array}{l}27 \\
32\end{array}$ & $\begin{array}{l}7.37 \\
9.14\end{array}$ & $\begin{array}{l}17 \\
88\end{array}$ & $\begin{array}{r}6.84 \\
10.13\end{array}$ & & & & \\
\hline \multirow[t]{2}{*}{ Model 4: 15-25 } & & & & & & 0.96 & 0.29 & 0.75 & 0.75 \\
\hline & Yes & $\begin{array}{r}108 \\
5\end{array}$ & $\begin{array}{r}8.88 \\
1136\end{array}$ & $\begin{array}{l}37 \\
14\end{array}$ & $\begin{array}{l}9.89 \\
842\end{array}$ & & & & \\
\hline
\end{tabular}

additional evidence concerning the optimal vancomycin dose and the corresponding pre-hemodialysis serum vancomycin concentration in this patient population.

The analysis showed that pre-hemodialysis serum vancomycin concentration was a function of baseline prehemodialysis serum vancomycin concentration, the maintenance dose of vancomycin, and interdialytic interval. This information was used to generate a prediction equation (Table 2), which was then used to calculate the targeted vancomycin dose, given particular values for baseline pre-hemodialysis serum vancomycin concentration, targeted pre-hemodialysis serum vancomycin concentration, and interdialytic interval. In addition, a datadriven cross-tabulation (Table 3) was generated to outline the various vancomycin doses that would be associated with specific values for baseline and target pre-hemodialysis serum vancomycin concentrations and interdialytic interval of $48 \mathrm{~h}$ versus $72 \mathrm{~h}$. According to this table, vancomycin dose should not be based exclusively on the targeted pre-hemodialysis serum concentration. Rather, clinicians must also factor in the baseline pre-hemodialysis serum vancomycin concentration and the interdialytic interval for a more precise estimate of the required dose.

These findings suggest that targeting a narrow prehemodialysis concentration of $15-20 \mathrm{mg} / \mathrm{L}$ is very restrictive, with an average required dose of $7 \mathrm{mg} / \mathrm{kg}$ or less when the pre-hemodialysis baseline value is around $15-20 \mathrm{mg} / \mathrm{L}$ and the interdialytic interval is $72 \mathrm{~h}$, a range that is not feasible for the majority of patients. Specifically, only $29.3 \%(n=48)$ of the observations in the current study had a measured pre-hemodialysis concentration of $15-20 \mathrm{mg} / \mathrm{L}$. This finding is consistent with the arguments of Vandecasteele and De Vriese ${ }^{1}$ and Jeremiah and others, ${ }^{18}$ who explained that achieving such a narrow range in patients undergoing hemodialysis is not practical. In fact, a post hoc analysis in the current study showed that only $36.0 \%$ ( $n=59$ ) of the observations fit within the range of $10-20 \mathrm{mg} / \mathrm{L}$, which further indicates that such a range of serum concentrations is not feasible in this patient population. Cut-off ranges of $10-25 \mathrm{mg} / \mathrm{L}$ and $15-25 \mathrm{mg} / \mathrm{L}$ were observed in $75.6 \%(n=124)$ and $68.9 \%(n=113)$ observations, respectively.

The goal was to report the range of cut-off points associated with the greatest sensitivity (i.e., the proportion of observations correctly classified as having a cut-off point within the specified range) and the highest positive predictive value (i.e., the likelihood that a given observation falls within the range of cut-off points into which the model has deemed the observation to fall). The study classification indices (Table 4) showed that the ranges of cut-off points of $15-20 \mathrm{mg} / \mathrm{L}$ and $10-20 \mathrm{mg} / \mathrm{L}$ were associated with low sensitivity (52\% and 53\%, respectively), which indicates that these 2 models have no better than a 50-50 chance of correctly classifying patients. Although Model 1 had the highest sensitivity $(97 \%)$ and the best predictive values, the range of cut-off points associated with this model was very wide (10-25 mg/L), which limits its clinical application. Model 4 presented the most clinically relevant range of cut-off points, $15-25 \mathrm{mg} / \mathrm{L}$, which was associated with an impressive sensitivity value of $96 \%$. Furthermore, this model had reasonable positive and negative predictive values (both 75\%), suggesting that it has $75 \%$ accuracy in correctly predicting the pre-hemodialysis serum vancomycin concentration in any given patient. Interestingly, the post hoc analysis indicated that the mean pre-hemodialysis concentration of the observations falling within this range of cutoff points was $20.5 \mathrm{mg} / \mathrm{L}$ (standard deviation 2.7; median 20.8).

The literature shows that variation in vancomycin dosing is associated with variability in pre-hemodialysis concentration and also that there is no consistency in reported pre-hemodialysis concentrations. For example, Pai and $\mathrm{Pai}^{19}$ and Ariano and others ${ }^{20}$ used a fixed maintenance dose of $500 \mathrm{mg}$ during the last 30-60 minutes of each hemodialysis session and achieved a pre-hemodialysis concentration of $5-20 \mathrm{mg} / \mathrm{L}$ in $93 \%$ and $96 \%$ of patients, respectively. However, current guidelines target a much narrower range of $15-20 \mathrm{mg} / \mathrm{L}$. Barth and DeVincenzo ${ }^{13}$ 
achieved a pre-hemodialysis serum vancomycin concentration of $10-25 \mathrm{mg} / \mathrm{L}$ in $82 \%$ of their observations, based on a maintenance dose of $500 \mathrm{mg}$ following completion of the hemodialysis session. Foote and others ${ }^{21}$ administered $1.0 \mathrm{~g}$ of vancomycin as a loading dose in 5 healthy hemodialysis patients and recommended a loading dose of $25 \mathrm{mg} / \mathrm{kg}$ in the final $1-2 \mathrm{~h}$ of dialysis, administered at a rate of $1 \mathrm{~g} / \mathrm{h}$. However, these investigators tested only a single dose of vancomycin. Similarly, Pollard and others ${ }^{22}$ recommended a loading dose of $20 \mathrm{mg} / \mathrm{kg}$ after dialysis, followed by a maintenance dose of $15 \mathrm{mg} / \mathrm{kg}$ every 7 days. Furthermore, Crawford and others, ${ }^{23}$ who prospectively administered a single dose of vancomycin $(35 \mathrm{mg} / \mathrm{kg})$ at the end of dialysis, at a rate of $1 \mathrm{~g} / \mathrm{h}$, to 11 patients, reported that a once-weekly dose of vancomycin $(35 \mathrm{mg} / \mathrm{kg})$ did not achieve a vancomycin concentration of at least $10 \mathrm{mg} / \mathrm{L}$ before the third scheduled hemodialysis session. Zvonar and others ${ }^{24}$ retrospectively evaluated 163 courses of vancomycin therapy in 105 patients at their institution and found that the most common dose was $500 \mathrm{mg}$ after or during the hemodialysis session. Panais and others ${ }^{25}$ administered a maximum loading dose of $1500 \mathrm{mg}$ vancomycin in 38 courses, followed by $500 \mathrm{mg}$ after each dialysis session and concluded that their protocol was successful in achieving a therapeutic trough concentration of the drug. The applicability of this dosing strategy is limited, because these authors used both high- and low-flux filters in their study. Taylor and Allon ${ }^{26}$ administered a maintenance dose of $1000 \mathrm{mg}$ in the last hour of hemodialysis and reported that $56 \%$ of patients had pre-hemodialysis concentration between 10 and $20 \mathrm{mg} / \mathrm{L}$ and only $23 \%$ had a pre-hemodialysis concentration between 20 and $25 \mathrm{mg} / \mathrm{L}$. Unlike the current study, all of the aforementioned studies either reported a wide range of pre-hemodialysis serum vancomycin concentrations or had a relatively small proportion of patients achieving the recommended range of $15-20 \mathrm{mg} / \mathrm{L}$. In the current study, a clinically meaningful pre-hemodialysis concentration of $15-25 \mathrm{mg} / \mathrm{L}$ was achieved for $68.9 \%$ of observations, which was also associated with the impressive sensitivity value of $96 \%$.

The current study and that of Vandecasteele and others ${ }^{6}$ identified similar variables (pre-hemodialysis vancomycin concentration, interdialytic interval, and body weight). Interestingly however, although both studies implemented a clustered approach to data analysis, the results of Vandecasteele and others $^{6}$ were validated using a 3-phase approach that included testing the model on a new sample of patients. Their model was validated using sensitivity and predictive values based on predicted pre-hemodialysis cut-off values. In contrast, Zelenitsky and others ${ }^{27}$ developed a new vancomycin dosing protocol to achieve a pre-hemodialysis concentration of $10-20 \mathrm{mg} / \mathrm{L}$, with an optimal goal of $15-20 \mathrm{mg} / \mathrm{L}$. Similar to the current study, patients in the study by Zelenitsky and other ${ }^{27}$ received a maintenance dose that ranged between 500 and $1000 \mathrm{mg}$. However, the pre-hemodialysis concentration was $10-20 \mathrm{mg} / \mathrm{L}$ for $65.5 \%$ of patients, $10-22 \mathrm{mg} / \mathrm{L}$ for $89.7 \%$, and $15-20 \mathrm{mg} / \mathrm{L}$ for only
$37.9 \%$. These findings further support the argument that a prehemodialysis concentration of $15-20 \mathrm{mg} / \mathrm{L}$ is restrictive and therefore may not be clinically feasible for a majority of patients undergoing hemodialysis. However, the models of both Vandecasteele and others ${ }^{6}$ and Zelenitsky and others ${ }^{27}$ were based on administration of vancomycin during the last $60 \mathrm{~min}$ of hemodialysis, whereas the model in the current study was based on administration of vancomycin after completion of the hemodialysis session. Moreover, Mason and others ${ }^{28}$ found that administering vancomycin $30 \mathrm{mg} / \mathrm{kg}$ in the last $1-2 \mathrm{~h}$ of hemodialysis achieved a similar pre-hemodialysis concentration as administering a vancomycin dose of $15 \mathrm{mg} / \mathrm{kg}$ after completion of the hemodialysis session. Similarly, Lucksiri and others ${ }^{15}$ detected that $24 \%$ of vancomycin was removed if the dose was administered during the last hour of dialysis, whereas none of the dose was lost if it was administered after completion of the session. Unlike most of the existing studies, maintenance doses of vancomycin in the current study and a few others ${ }^{13,28-30}$ were always administered after completion of hemodialysis. These differences are worthy of mention because they affect the net dose of vancomycin received. Thus, it is important that clinicians follow a uniform protocol for vancomycin dosing, including the timing of administration.

The limitations of this study include collection of data from patients with stage $5 \mathrm{CKD}$ who were undergoing hemodialysis, without consideration of whether the patients might have had residual renal function. The interdialytic interval was not exactly 48 versus $72 \mathrm{~h}$ because samples for pre-hemodialysis measurements were drawn within $6 \mathrm{~h}$ before the procedure, whereas vancomycin doses were administered within $6 \mathrm{~h}$ after completion of hemodialysis. In addition, the cross-tabulation results (Table 3) for determining the required dose (based on knowledge of baseline pre-hemodialysis serum vancomycin concentration, target pre-hemodialysis serum vancomycin concentration, and interdialytic interval) did not include all possible dose scenarios. It is recommended that these findings be interpreted with caution and that they be replicated and validated before any implementation in practice settings. Finally, data for patient weight was calculated from the average of wet and dry weights as documented in the electronic medical records. In addition, mean patient weight had a relatively large standard deviation, which resulted in a wide range and large standard deviation for the weight-based dose $(\mathrm{mg} / \mathrm{kg})$; this might have compromised the predictive ability of the regression equation. Therefore, it is recommended that these findings be validated with samples that are more homogeneous with regard to body weight.

\section{CONCLUSION}

The findings of the current study and those of several other authors indicate that targeting a pre-hemodialysis concentration of $15-20 \mathrm{mg} / \mathrm{L}$ may be highly restrictive; this target is unlikely to be achieved in the majority of patients, and the associated 
outcomes have not yet been established in clinical studies. The current findings support a more liberal, yet clinically meaningful, range of $15-25 \mathrm{mg} / \mathrm{L}$, which yielded considerable sensitivity (96\%) and a positive predictive value of $75 \%$. However, the current findings were based on an observational cohort study and are therefore subject to potential bias. Furthermore, they have not yet been validated or replicated with another sample. In addition, the effect that a range of $15-25 \mathrm{mg} / \mathrm{L}$ could have on the residual renal function of this particular patient population is unclear. It is therefore recommended that these findings be replicated and their effect on the residual function of patients with stage $5 \mathrm{CKD}$ be investigated before any practice generalizations.

\section{References}

1. Vandecasteele SJ, De Vriese AS. Recent changes in vancomycin use in renal failure. Kidney Int. 2010;77(9):760-4.

2. Pallotta KE, Manley HJ. Vancomycin use in patients requiring hemodialysis: a literature review. Semin Dial. 2008;21(1):63-70.

3. El Nekidy WS, El-Masri MM, Umstead GS, Dehoorne-Smith M. Factors influencing vancomycin loading dose for hospitalized hemodialysis patients: prospective observational cohort study. Can J Hosp Pharm. 2012;65(6): 436-42.

4. Vandecasteele SJ, De Vriese AS. Vancomycin dosing in patients on intermittent hemodialysis. Semin Dial. 2011;24(1):50-5.

5. Jones RN. Key considerations in the treatment of complicated staphylococcal infections. Clin Microbiol Infect. 2008;14 Suppl 2:3-9.

6. Vandecasteele SJ, De Bacquer D, De Vriese AS. Implementation of a dose calculator for vancomycin to achieve target pre-HD concentrations of 15-20 microg/mL in persons undergoing hemodialysis. Clin Infect Dis. 2011;53(2):124-9.

7. Crawford BS, Largen RF, Walton T, Doran JJ. Once-weekly vancomycin for patients receiving high-flux hemodialysis. Am J Health Syst Pharm. 2008;65(13):1248-53

8. Zoer J, Schrander-van der Meer AM, van Dorp WT. Dosage recommendation of vancomycin during haemodialysis with highly permeable membranes. Pharm World Sci. 1997;19(4):191-6.

9. Rybak M, Lomaestro B, Rotschafer JC, Moellering R Jr, Craig W, Billeter M, et al. Therapeutic monitoring of vancomycin in adult patients: a consensus review of the American Society of Health-System Pharmacists, the Infectious Diseases Society of America, and the Society of Infectious Diseases Pharmacists. Am J Health Syst Pharm. 2009;66(1):82-98. Erratum in: Am J Health Syst Pharm. 2009;66(10):887.

10. American Thoracic Society; Infectious Diseases Society of America. Guidelines for the management of adults with hospital-acquired, ventilatorassociated, and healthcare-associated pneumonia. Am J Respir Crit Care Med. 2005;171(4):388-416

11. Liu C, Bayer A, Cosgrove SE, Daum RS, Fridkin SK, Gorwitz RJ, et al. Clinical practice guidelines by the Infectious Diseases Society of America for the treatment of methicillin-resistant Staphylococcus aureus infections in adults and children. Clin Infect Dis. 2011;52:e18-e55. Erratum in: Clin Infect Dis. 2011;53(3):319.

12. Brown M, Polisetty R, Gracely EJ, Cuhaci B, Schlecht HP. Weight-based loading of vancomycin in patients on hemodialysis. Clin Infect Dis. 2011; 53(2):164-6.

13. Barth RH, DeVincenzo N. Use of vancomycin in high-flux hemodialysis: experience with 130 courses of therapy. Kidney Int. 1996;50(3):929-36.

14. Welage LS, Mason NA, Hoffman EJ, Odeh RM, Dombrouski J, Patel JA, et al. Influence of cellulose triacetate hemodialyzers on vancomycin pharmacokinetics. J Am Soc Nephrol. 1995;6(4):1284-90.

15. Lucksiri A, Scott MK, Mueller BA, Hamburger RJ, Sowinski KM. CAHP210 dialyzer influence on intra-dialytic vancomycin removal. Nephrol Dial Transplant. 2002;17(9):1649-54.

16. Scott MK, Mueller BA, Clark WR. Vancomycin mass transfer characteristics of high-flux cellulosic dialysers. Nephrol Dial Transplant. 1997; 12(12):2647-53.
17. Scott MK, Macias WL, Kraus MA, Clark WR, Carfagna MA, Mueller BA. Effects of dialysis membrane on intradialytic vancomycin administration. Pharmacotherapy. 1997;17(2):256-62.

18. Jeremiah CJ, Wills C, Bayly A, Perry GJ, Davis JS, Tong SY, et al. Vancomycin dosing nomogram for haemodialysis patients. Nephrology (Carlton). 2014;19(8):513-4.

19. Pai AB, Pai MP. Vancomycin dosing in high flux hemodialysis: a limited sampling algorithm. Am J Health Syst Pharm. 2004;61(17):1812-6.

20. Ariano RE, Fine A, Sitar DS, Rexrode S, Zelenitsky SA. Adequacy of a vancomycin dosing regimen in patients receiving high-flux hemodialysis. Am J Kidney Dis. 2005;46(4):681-7.

21. Foote EF, Dreitlein WB, Steward CA, Kapoian T, Walker JA, Sherman RA. Pharmacokinetics of vancomycin when administered during high flux hemodialysis. Clin Nephrol. 1998;50(1):51-5.

22. Pollard TA, Lampasona V, Akkerman S, Tom K, Hooks MA, Mullins RE, et al. Vancomycin redistribution: dosing recommendations following highflux hemodialysis. Kidney Int. 1994;45(1):232-7.

23. Crawford BS, Largen RF, Walton T, Doran JJ. Once-weekly vancomycin for patients receiving high-flux hemodialysis. Am J Health Syst Pharm. 2008; 65(13):1248-53.

24. Zvonar R, Natarajan S, Edwards C, Roth V. Assessment of vancomycin use in chronic haemodialysis patients: room for improvement. Nephrol Dial Transplant. 2008;23(11):3690-5.

25. Panais R, Hirsch DJ, Dipchand C, Storsley L, Finkle SN. A protocolized approach to vancomycin dosing in conventional hemodialysis. J Nephrol. 2010;23(5):569-74.

26. Taylor ME, Allon M. Practical vancomycin dosing in hemodialysis patients in the era of emerging vancomycin resistance: a single-center experience. Am J Kidney Dis. 2010; 55:1163-5.

27. Zelenitsky SA, Ariano RE, McCrae ML, Vercaigne LM. Initial vancomycin dosing protocol to achieve therapeutic serum concentrations in patients undergoing hemodialysis. Clin Infect Dis. 2012;55(4):527-33.

28. Mason NA, Neudeck BL, Welage LS, Patel JA, Swartz RD. Comparison of 3 vancomycin dosage regimens during hemodialysis with cellulose triacetate dialyzers: post-dialysis versus intradialytic administration. Clin Nephrol. 2003;60(2):96-104.

29. Lin SY, Shen MC, Hwang SJ, Chen YH, Chen TC, Chiu YW, et al. Evaluation of vancomycin dosing protocols to achieve therapeutic serum concentrations in patients receiving high-flux haemodialysis. Int J Antimicrob Agents. 2014;43(4):384-5.

30. Brown M, Polisetty R, Gracely EJ, Cuhaci B, Schlecht HP. Weight-based loading of vancomycin in patients on hemodialysis. Clin Infect Dis. 2011;53(2):164-6.

Wasim S El Nekidy, PharmD, BCPS, BCACP, was, at the time of this study, a Resident at St John Hospital and Medical Center in Detroit, Michigan. At the time of submission, he was a Clinical Pharmacy Specialist with the Departments of Pharmacy and Nephrology, Windsor Regional Hospital, Windsor, Ontario, and he is now a Senior Pharmacotherapy Specialist Nephrology with the Department of Pharmacy, Cleveland Clinic Abu Dhabi, United Arab Emirates.

Maher M El-Masri, PhD, RN, is Professor and Research Leadership Chair, Faculty of Nursing, University of Windsor, Windsor, Ontario.

Greg S Umstead, PharmD, is a Clinical Pharmacy Specialist, St John Hospital and Medical Center, Detroit, Michigan.

Michelle Dehoorne-Smith, PharmD, is Manager of Patient Care Services, St John Hospital and Medical Center, Detroit, Michigan.

Competing interests: None declared.

\section{Address correspondence to:}

Dr Wasim S El Nekidy

Department of Pharmacy

Cleveland Clinic Abu Dhabi

PO Box 112412

Abu Dhabi, United Arab Emirates

e-mail: elnekiw@clevelandclinicabudhabi.ae

Funding: None received.

Acknowledgment: The authors sincerely acknowledge the invaluable contributions and insights of Bruce A Mueller, PharmD, FCCP, FASN, FNKF, Professor and Associate Dean of Academic Affairs, University of Michigan College of Pharmacy. 